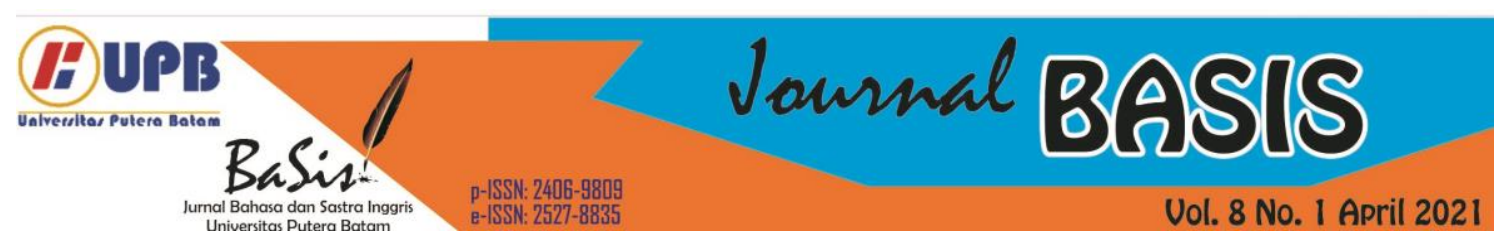

\title{
HEROINE AND PRINCESS: WOMEN IMAGE PORTRAYED IN SELECTED DISNEY'S STORIES
}

\author{
Resneri Daulay \\ Universitas Ahmad Dahlan, Yogyakarta, Indonesia \\ resneri.daulay@enlitera.uad.ac.id.
}

\begin{abstract}
The purpose of this study is to revealed the women image portrayed in selected Disney's stories. There are several stories of Disney's movie adaptation that are used as object in this research. There are Sleeping Beauty (Disney, 2014), Snow White (Brothers Grimm, 1812), Beauty and The Beast (Gabrielle-Suzanne Barbot, 1740), Cinderella (Giambattista Basile, 1634), Mulan (Guo Maoqian, 1992), and Brave (Disney, 2012). In addition, the aim of this research is also to identify the characteristics of female characters in selected Disney's stories related to the Heroine and Princess attitude. This study used qualitative research; descriptive qualitative methods are used to analyze data. This study used three main concepts of semiotics theory by Roland Barthes, there are meaning of denotation, connotation, and myth. This study also applied feminism approach accordance to women attitude as heroine and princess. In this study, the researcher found some results. First, this study indicated the women image portrayed in Disney's stories contains two images, they are women as heroine and princess. Women image as heroine is revealed in Beauty and the Beast, Mulan and Brave. Meanwhile, women as princess is portrayed in Sleeping Beauty, Snow White and Cinderella. Then, there are several characteristics found in Disney's stories that represent the woman's character as heroine and princess. They are from the feminism such as submissive, kind and gentle, domestic role, damsel in distress, emotional balance, craving for freedom (independent and brave), willing to sacrifice and has ability to stand up to the antagonist.
\end{abstract}

Keywords: Heroine, Princess, Women Image, Disney’s Stories

\section{INTRODUCTION}

Children literature is an important part of the development of a child's knowledge. Through books read or films watched by children, it becomes valid knowledge and will be remembered until adulthood. Therefore, it is necessary to pay attention to the context and values that are presented in children literature.

Walt Disney is a world-renowned producer who has produced hundreds of films adapted from various classical literature. The stories that are narrated through the Disney films are very popular with many people, especially children. Thus, these Disney stories are often used as examples by children in various aspects of life. One of the Disney achievements in film industry is that his film has succeeded in replacing the reader's desire to know these stories in books through the pleasure of watching of movies as entertainment. Therefore, the researcher examines one important aspect that is often portrayed in Disney stories, namely women image. Some stories that will be analyzed are Sleeping Beauty (Disney, 2014), Snow White (Brothers Grimm, 1812), Beauty and the Beast (GabrielleSuzanne Barbot, 1740), Cinderella (Giambattista Basile, 1634), Mulan 
(Guo Maoqian, 1992), and Brave (Disney, 2012).

Due to women representation is often depicted in literary work, the researcher focuses on how women character portrayed in Disney's stories as an object in this research. This research uses a semiotics theory by Roland Barthes, namely by looking in detail and the structure of the characters and characterizations through signified and signifier of women image in Disney's stories, so that it can be seen what kind of image that the author describes. This semiotics theory will reveal the meaning of the text in the stories by using three aspects. They are denotation, connotation and myth. By using a semiotic analysis, the researcher will reveal the women image from various characters in selected Disney's stories.

\section{LITERATURE REVIEW}

There are several studies that relevant to this research. They have same similarity and difference to this research that it can be also as reference to this research. First, a research entitled Gender Representation in Children's Literature: 1900-1984. It was written by Elizabeth and Bernice A. Pescosolido (1989). This research examined trends in the presence and centrality of men and women in American Children book in $20^{\text {th }}$ century. The theme about children stories and gender, men and women, focused is the related topic to this research. Meanwhile, it has different object used that is between American children story and selected Disney's stories.

Second, Jill P. May published her article entitled Walt Disney's Interpretation of Children Literature. This research showed that Disney is a part of children's literature that must be recognized. There are a lot of values of life that related to the U.S. culture. She also critics how Disney restructure the children classic stories. While, this research focuses on the woman character rather than cultural aspects.

This research used Semiotics theory by Roland Barthes. Semiotic is the study of signs (Berger, 2010; 1). Sign is defined as something that can be used to interpret other meaning. A sign can be called as a sign if the sign is interpreted as a sign. Barthes develops semiotics into two stages of signs, namely denotation and connotation. Besides that, Barthes also develops interpreting aspects namely myth.

The meaning in the first stage, Barthes called it as denotation. The development of denotation meaning is connotation meaning. In the third stage of meaning, Barthes stated that extension of the meaning of the connotation is a myth. To interpret the signs in an object, an experience based on social reality is needed to interpret the sign. According to Berger (2010: $65)$, he stated that denotation is a direct meaning, and it can be called as a description for a sign. Meanwhile, the meaning of connotation is the process of meaning associated with the knowledge of the meaning. Myth is not explained through the object of the message, but myth is conveyed through the object conveying its message. The connotation marking system develops into an ideology in society known as myth.

\section{RESEARCH METHOD}

This research used objective approach. It emphasizes on the aspects in a literary work. The aspects are from intrinsic aspects. The method of analyzing data is descriptive qualitative analysis. Starting from reading the stories and also understanding every 
conversation of the main character with another character, the behavior of the main character, and others. Then the researcher browses some website to understand the theory, and also understand the theory by reading the book of theory. Furthermore, the researcher choosing Roland Barthes' theory named semiotics as a theory for analyzing this research.

The researcher using this theory because the image of women reveals by identifying the meaning from the signified and signifier through the dialogue in the stories. The researcher connected the meaning to the feminism approach, in this case, Heroine and Princess attitude that is shown by woman character in selected Disney's stories.

The method of analyzing data is done based on the semiotic theory used. It is that there are three stages followed, namely denotation, connotation, and myth meaning. The meaning of the text related to the women images will reveal through the signs in the three stages.

\section{RESULT AND DISCUSSION}

There are several images of women that is recognized by analyzing the women character in selected Disney's stories. The images concluded that the women representation in Disney's stories consists of two images, namely heroine and princess. The explanation below showed how women images in Disney's stories.

1. Feminism Trait

a) Kind and gentle

Snow White kneeled to soothe a baby that had fallen from its nest.

"Oh, Please don't cry" she said (Snow White, page 11)

Detonation: The quote is about Snow White who help a baby bird and gently calming the baby bird.
One morning, Jaq the mouse rushed in to tell Cinderella that a new mouse was caught in a trap! Cinderella hurried down to the cellar to rescue him. (Cinderella, page 8)

Detonation: The quote is about Cinderella who immediately goes to help a mouse caught in a trap.

Connotation: A feminine woman will have the characteristics of someone who is loving, compassionate, kind, helpful, humble and sincere

Myth: The myth in this case is that a woman is required to behave gently, politely, helpful and kind. From childhood, children have been given a description by their parents and even the environment for how they act or behave as a woman

b) Submissive

"Take that ironing." Drizela demanded.

"Don't forget to make out tea." Anastasia added.

"Pick up the laundry and get on with your duties," her stepmother ordered. (Cinderella, page 13)

Detonation: this quote is about Cinderella listening to the household chores she was told to do.

Connotation; women must obey those who are older or superior to them. They just accept and listen to what they have to do, without interrupting or arguing.Myth; the myth that develops in society is that women must be obedient. The submissive nature of women is reflected in the calmness, obedience, grace, and patience that every woman in society demands. They describe perfect women because they fulfill every aspect that society expects.

2. Damsel in Distress

The handsome Prince had searched far and wide for the girl he had met at the well that morning. When he 
come to the clearing where Snow White lay, he kneeled down and with great sorrow, kissed her farewell. It was Love's First Kiss! With soft sigh, Snow White sat up and rubbed her eyes. (Snow White, page 61)

The bird and forest animals raced to the diamond mine to warn the dwarfs. They pulled their sleeves and pushed them from behind At last, the dwarf understood.

"The Queen! Snow White!" Doc cried.

"We've got to save her!" Grumpy shouted. (Snow White page 49)

Detonation: In Snow White and the Seven Dwarfs, Snow White is depicted as a naïve princess who relies on her seven male friends and a prince to survive. Snow White needs a kiss of true love from her Prince Charming to live and the seven dwarves try to save Snow White from the Evil Queen. And the other quote is about a handsome prince who came looking for his ideal woman and then kissed her and it turned out that it saved Snow White from poison / curse from the evil queen.

Philip quickly made his way to the castle tower where Aurora lay sleeping. When he reached her bedside, he knelt down and finally kissed his one true love. Aurora's eyes fluttered open, and she smiled. The spell was broken. (Sleeping Beauty, page 66)

Connotation: the quote above is about a prince Philip who came to save Aurora from the curse of the Maleficent fairy. And with a kiss of true love, Aurora breaks the curse of sleep.

Myth; the quote above describes a man who saves a woman. This can be called Damsel in Distress. Damsel in Distress is a classic term in the world of literature, art, and film to describe a young female character who is in a difficult situation and needs a male hero to save her. Usually, the female character has problems that she cannot solve on her own. After being saved, the female character will usually marry the hero who saved her. The myth contained in this quote is that in society, women are characters who expect help from a man. Strengthens the stereotype that women depend on men and the only way to feel safe is to be protected by men. Women passively wait for men to help them and save them from misery.

3. Domestic Role

"Cinderella spent the rest of her day attending to chores" (Cinderella,

"If you let me stay, I'll wash and sew and cook," Snow White promised (Snow White, page 29)

Detonation: the quotes above are about Snow White and Cinderella doing various household chores

Connotation: The quote above explains that Snow White volunteered to offer himself to cook, wash and clean the house of the seven dwarves so that he could live in the house of the seven dwarves. And Cinderella, who was enslaved by her stepfamily to do household chores.

Myth: the myth of this quote is that at that time women had a role as housewives. The women have domestic work because they are very neat, and care very well. They do a variety of household chores very well. They do the expected gender role, namely as a housewife who does household chores. So far, women can get their identity and role in society when they get married and become mothers. That the duty of women is to manage the household. Women's work focuses on the domestic sphere, namely doing various homework to form perceptions and 
judgments in society that the focus of a woman's work is on the domestic role.

4. Emotional imbalance

They danced and danced, gazing deeply into each other's eyes ... the two were falling in love. (Cinderella, p.43)

The prince began to sing along with Briar Rose. Then they started dancing together and fell in love. (Sleeping Beauty, page 29)

The handsome Prince had searched far and wide for the girl he had met at the well that morning. When he come to the clearing where Snow White lay, he kneeled down and with great sorrow, kissed her farewell. It was Love's First Kiss! (Snow White, p. 61)

Detonation: the quote above is about female characters who fall in love with their handsome prince.

Connotation: The female characters in Disney stories are described as highly experienced characters whose names fall in love with the male characters in their stories. They met the prince, sang or danced together and then fell in love with each other forever. Disney did not show the process of falling in love. For them the instantaneous reaction meant eternal love.

5. Craving for Freedom (Independent) In a small village nearby lived a beautiful young woman named Belle. As she entered the town bookstore, the owner gave her a book as a gift. "It's my favorite! Far-off places, daring sword fights, magic spells, a prince in disguise... oh, thank you very much!" Belle rushed outside, reading as she walked. (Beauty and the Beast)

Denotation: In the conversation at the beginning of the story, where Belle talks to herself about the book she read
"It's my favorite! far-off places, online sword fights, magic spells, a prince in disguise ... " It seems that belle likes books on freedom, sword fighting, which shows women with Freedom, a heroine of sorts, with both a voice and a desire for adventure.

Connotation: In the picture, Belle is reading a book about war, freedom, which is usually more interesting to read by men. However, this story is for a Belle who, walks happily, is focused and ambitious, imaginative and loves to read a story to see another side of provincial life which she thinks is boring.

Myth: The state of society those who like to stay in a place, do what the tradition does in the small town, while the belle side is full of curiosity, and adventurous, likes freedom, wants to always look for something else outside provincial life.

Independent woman is also portrayed in Brave that is shown by Merida.

Then Merida appeared on the fireld. "I am the firstborn descendant of Clan Dunbroch!" she declared. "And I will be shooting for my own hand!" "I forbid it!" Queen Elinor cried. But merida ignored her mother and took aim. (Brave)

Denotation: seen from the sentence "I'm the Firstborn descendant of clan DunBroch and I'll be shooting for my own hand" the heroine side which shows that he is tough and choose archery as the challenge to determine her betrothed. She wants to find her voice against anything she does not believe in her own choice.

Connotation: As the firstborn of DunBroch, Merida declares that she has the right to compete in the archery contest. Nobody can limit her, even her mother forbids her, Merida ignored her mother and took aim., It appears that the 
crowds who have gathered to watch the competition are more than a little surprised because Merida enters and wins the contest herself. Merida also Trues to herself, When the queen wants her to look like a princess, Merida doesn't want to hide her hair or her personality, she let her hair free.

Myth: The post-feminist princess embodies the ideals of feminism while representing the pressures and entrapment of pre-feminist culture. by society through marriage pressure and royal status, this is related to Merida who is required to participate in an arranged marriage as a result of competition.

\section{Brave}

Merida run out of the castle. Sobbling, she jumped on her horse and raced into the forest. Soon she arrived at the mysterious Ring of Stones. Tiny blue lights appeared, forming a trait. "They seemed to beckon Merida deeper into the forest. (Brave)

Denotation: It can be seen from the heroine side that Merida ran into the forest only with her horse, which is not done by other princesses who go anywhere with the royal guards, and must be guarded by her security, Merida is independent, brave, and confident with full ambition and courage.

Connotation: When Merida ran out of the castle, and jumped on her horse and raced into the forest, the connotation that depicts the heroine side implied is Merida seeking freedom, if the royal princesses will generally obey the rules and whatever Queen says, they will submit. and accept whatever the decisions are. But Merida took a risk, she ran away, because she did not agree with the queen's statement of the tradition of marriage in the kingdom.

Myth: Scotland is an ancient place, filled with natural and supernatural wonders. And there's the circle of standing stones, where Merida's horse refuses to cross them and it is here that she sees the mysterious wisps (more on those later!) which lead her to the witch's cottage.

7. Willing to sacrifice

That night, Mulan watched her father practiced sword fighting. Seeing him fall, she knew he was not strong enough to survive another war. She made a decision. Moving quietly, Mulan took Fa Zhou's conscription orders from his table and left her mother's hair comb in its place. She cut her hair short with her father's sword and dressed in his armour. (Mulan)

Denotation: Mulan made the decision when she learned that her father had fallen. seen cutting her hair, to disguise herself as a boy. He used a sword to cut his hair, not scissors, and other tools. she's confident wielding a sword.

Connotation: Mulan is loyal to her family, she longs to bring honor to her family, she wants to save her father in disguise, looks heroine when she makes decisions, she is not afraid to take risks, because she's tough and strong, she rarely gives up, even when the odds are against her. This is reaffirmed in 'Reflection' when Mulan conveys her desire to be the perfect bride and daughter, but also acknowledges that this may never be possible for her. This belief that she is flawed leads to her decision to take her father's place; if she cannot be the perfect female, then maybe she will be a better male.

Myth: Society to act requires a strong and Tough soldier, by relocating this critique to ancient China, and creating overtly sexist male characters, the message comes across as a criticism 
of the repressive ancient Chinese government, Mulan against her repressive environment, the story of Mulan for throwing off the conventional Disney princess attributes of demure beauty to save her country.

8. Has ability to stand up to the antagonist

Soon, a hunter named Gaston walked up to her. He grabbed the bok from her hands. "It's about time you got your nose out of those books and paid attention to more important things- like me."

At home, Belle heard a knock on the door. "Gaston!"

"Belle, there is not a girl in town who wouldn't love to be in your shoes. Do you know why? Because I want to marry you!"

Belle turned his proposal down. She did not like the conceited bully. Disappointed, Gaston left. (Beauty and the Beast)

Denotation: From the conversation, it appears that Gaston wants Belle to marry him. The heroine side that was seen when belle refused him without a second thought. The Heroine of Belle's attitude describes the existence of rejection, freedom. It implies that a woman has the right to choose and determine her choice, even though it can be seen from the picture of a rich Gaston, Bossy by lifting both his feet on the table, and Belle still does not accept the arrogant Gaston.

Connotation: The implied connotation states that there is a heroine trait which indicates that Belle is not innocent, weak, and firmly. She rejects Gaston which is actually rich, and can make belle's life secure. But Belle is not a pure maiden innocence, she is not looking for something that makes her lose money, she knows that happiness is not when marrying a rich person. Belle is an independent and doesn't need Gaston to survive. And in the last sentence, It can be seen that the role of Gaston (the man) there is not pushy. Dan was disappointed by Belle's stern and rebellious attitude, and he finally left.

The myth here can be traced back to that era, according to (UBC Wiki, 2017) which states that "This transition of feminist ideology was reflected in the next generation of Disney films. The Little Mermaid (1989), Beauty and the Beast (1991), Aladdin (1992), Pocahontas (1995) and Mulan (1998) presented a new batch of Princesses who all demonstrated more progressive attitudes and character development than in the Classic Disney Era ", Which at that time was Disney Renaissance Era and Second / Third Wave Feminism, The second wave of feminism was set off in the 1960s and focused primarily on women's legal and social equality through the abandonment of sexism and misogyny. (Parks, 2014) Gaston who views himself as having a high degree with confidence that he can marry anyone, including belle, by cheating to marry Belle, bring Belle will be lucky if he married him, He described Belle who only lived with her father, would accept it.

\section{CONCLUSION}

In this study, the researcher found some results. First, this study indicated the women image portrayed in Disney's stories contains two images, they are women as heroine and princess. Women image as heroine is revealed in Beauty and the Beast, Mulan and Brave. Meanwhile, women as princess is portrayed in Sleeping beauty, Snow White and Cinderella. Then, there are several characteristics found in Disney's stories that represent the 
woman's character as heroine and princess. They are from the feminism such as submissive, kind and gentle, domestic role, damsel in distress, emotional balance, craving for freedom (independent and brave), willing to sacrifice and has ability to stand up to the antagonist.

\section{REFERENCES}

Berger, Arthur Asa. (2010). Pengantar Semiotika. Yogyakarta: Penerbit Tiara Wacana

Dagun, Save M. (1992). Maskulin dan Feminin: Pria dan Wanita dalam Fisiologi, Psikologi, Seksual, Karier dan Masa Depan. Jakarta: Rineka Cipta

Disney. (2020). Mulan, Disney Collection, Special Disney Storybook Series, New York: Disney

D'Risco, E. (2012). Brave. New York: Disney Press, Pixar

Fakih, Mansour. (2003). Analisis Gender dan Transformasi Sosial. Yogyakarta: Pustaka Pelajar

Graerholz, Elizabeth dan Pescosolido, Bernice. (1989). Gender Representation in Children's Literature: 1900-1984. Retrieved on 27 January 2020 http://www.jstor.org/stable/19004?s $\underline{\text { eq }}=1 \&$ cid $=$ pdf - reference_tab_contents

Harnawi, Septia Martha dan Roekhan. (2013). Citra Tokoh (Srintil) dalam Novel Ronggeng Dukuh Paruk Karya Ahmad Tohari. Universitas Negeri Malang. JPBSIOnline

May, Jill P. (1981). Walt Disney's Interpretation of Children;s Literature. Retrieved on 20 January 2020

https://www.jstor.org/stable/41961 $\underline{352}$

Nurgiantoro, Burhan. (2007). Teori Pengkajian Fiksi. Gadjjah Mada: University Press

Ratna, Nyoman Kutha. (2012). Teori Metode dan Teknik Penelitian Sastra. Yogyakarta: Pustaka Pelajar

Sarumpaet. (2010). Pedoman Penelitian Sastra Anak. Jakarta: Yayasan Pustaka Obor Indonesia

Sheridan, J. (2010). Beauty and The Beast. New York: Disney Press

Soeratno, S Chamammah. (2011). Sastra: Teori dan Metode. Yogyakarta: Elmatera

Stover, Cassandra. (2013). Damsels and Heroines: The Conundrum of the Post-Feminist Disney Princess, 2.1.

Sugihastuti dan Suharto. (2010). Kritik Sastra Feminisme, Teori dan Aplikasinya. Yogyakarta: Pustaka Pelajar. 